\title{
Effective Gold Recovery from Near-Surface Oxide Zone Using Reductive Microwave Roasting and Magnetic Separation
}

\author{
Bong-Ju Kim ${ }^{1}$, Kang Hee Cho ${ }^{2}$, Sang-Gil Lee ${ }^{1}$, Cheon-Young Park ${ }^{3}$, Nag-Choul Choi ${ }^{2, *}$ and \\ Soonjae Lee ${ }^{1, *(D)}$ \\ 1 Department of Earth and Environmental Sciences, Korea University, Anam-ro 145, Sungbuk-gu, Seoul 02841, \\ Korea; kbj7878@korea.ac.kr (B.-J.K.); sg0403@korea.ac.kr (S.-G.L.) \\ 2 Department of Rural Systems Engineering/Research Institute of Agriculture and Life Sciences, Seoul \\ National University, Seoul 08826, Korea; kanghee1226@hanmail.net \\ 3 Department of Energy and Resource Engineering, Chosun University, Gwangju 61452, Korea; \\ cybpark@chosun.ac.kr \\ * Correspondence: nagchoul@empas.com (N.-C.C.); soonjam@korea.ac.kr (S.L.); \\ Tel.: +82-62-230-7878 (N.-C.C.); +82-2-3290-3177 (S.L.)
}

Received: 23 October 2018; Accepted: 15 November 2018; Published: 16 November 2018

check for updates

\begin{abstract}
High content of gold in near-surface oxide zones above the gold ore deposit could be recovered using cyanidation. However, restricting the use of cyanide in mines has made it difficult to recover gold within the oxide zone. In this study, we investigated an application of the reductive microwave roasting and magnetic separation (RMR-MS) process for the effective gold recovery from ores in a near-surface oxide zone. Ore samples obtained from the near-surface oxide zone in Moisan Gold Mine (Haenam, South Korea) were used in RMR-MS tests for the recovery of iron and gold. The effect of the RMR process on the recovery of iron and gold was evaluated by given various conditions of the microwave irradiation as well as the dosages of reductant and additive. The microwave roasting resulted in a chemical reduction of non-magnetic iron oxide minerals (hematite) to magnetite minerals, such as magnetite and maghemite. This mineral phase change could induce the effective separation of iron minerals from the gangue minerals by magnetic separation process. The increased iron recovery was directly proportional to the gold recovery due to the coexistence of gold with iron minerals. The RMR-MS process could be a promising method for gold recovery from the ores in near-surface oxide zones.
\end{abstract}

Keywords: gold recovery; oxide zone; reductive microwave roasting; magnetic separation; Fe-oxide; mineral phase change

\section{Introduction}

Gossans (or iron cap) are highly oxidized and weathered rock, usually associated with the upper and exposed parts of an ore deposit or mineralized vein, and so it was an important guide to find the buried gold ore deposits in the 19th and 20th centuries. Gold is captured during the formation of Fe-oxide, either internally or where concentric structures are produced [1]. In the oxide zone, refractory gold is found together with hematite as coatings or internal cements in goethite, saprolite, laterite, Al-hydroxide, and ilmenite.

The recovery of precious metals such as gold from refractory ores has received considerable attention [2-6]. To achieve a satisfactory recovery, a pretreatment stage is required to break down or at least to modify the matrix and release the precious metals before applying any conventional treatment [7]. A suitable pre-treatment process, such as roasting [8], pressure oxidation [9], 
bio-oxidation [10], alkaline [7] or alkaline sulfide leaching [11] and, to a limited extent, ultrafine grinding [12], is often required to overcome refractoriness and render the encapsulated gold and silver accessible to the lixiviant action of cyanide and oxygen.

Several processes have been used for treating a sulfidic refractory gold ore, such as oxidation roasting, biological oxidation, Albion process, leachox process, pressure oxidation and flotation-preoxidation-cyanidation methods $[13,14]$. However, an improved method is needed to separate and recover high-grade $\mathrm{Au}$ from the mineralized oxidized zone, because a high percentage of $\mathrm{Au}$ in hematite cannot be recovered by the cyanidation process. Iron-oxide-bearing refractory gold yields low gold and silver extractions in cyanide leaching [15]. Under high $\mathrm{pH}$ of cyanide, the dissolved iron oxide adsorbs on the gold surface, inhibiting the cyanide dissolution of the gold (passivation) [16-18]. The commonly used flotation method cannot separate Au-containing hematite or clay minerals directly from gangue minerals, because the low hydrophobicity of the minerals coating clay particles reduces the efficiency of flotation separation $[1,6,19,20]$.

Roasting processes have been applied for gold recovery as a pretreatment. Dunn and Chamberlain [8] used a two-step roasting process for gold recovery from hematite to exclude the generation of $\mathrm{FeAsO}_{4}$ and As in the air. After the two-step roasting, gold contained in hematite could be leached and extracted effectively with cyanide or non-cyanide solvent. But the two-step roasting required a large amount of cost and facilities [21].

Microwave roasting can shorten the processing time, in contrast with traditional methods that use electric furnaces. Several studies have used microwave reductive roasting to convert hematite or siderite (Fe-oxide minerals) and goethite (Fe-hydroxide mineral), into magnetite [22-24]. Since microwaves selectively react to specific iron minerals, thermal stress occurs at the boundary between gangue and iron minerals [4], and this thermal stress incurs microcracks at the boundary of minerals whose thermal expansion coefficient is different from each other, or inside the minerals [22]. Very high temperature obtained in the boundaries could also produce thermal fracturing [23,25]. The generated microcracks and faults are ultimately followed by thermal fracturing, and this thermal fracturing degrades the strength of the iron minerals, thereby facilitating the crushing and milling of ore minerals, resulting in increased Au liberation efficiency from gold ore [6,26].

After the mineral phase is changed through the microwave treatment, it is possible to use another technique for recovering the refractory gold from the oxide zone. However, few studies have considered recovery of refractory gold in the near-surface oxide zone and the applicability of the microwave roasting for concentrating gold. In this study, we investigated a method for gold concentration from the ores in near-surface oxide zone using the reductive microwave roasting and the magnetic separation processes. The mineralogical phase change of Fe-oxides was tested under various conditions of reductive microwave roasting (RMR). After magnetic separation (MS) of the treated concentrate, effect of RMR-MS process on enhancing Au content and Fe recovery was evaluated.

\section{Materials and Methods}

\subsection{Ore in the Near-Surface Oxide Zone}

Ore samples were collected from the near-surface oxide zone at $25 \mathrm{~m}$ below sea level at the Moisan Gold deposit in Haenam, South Korea. Moisan deposit is part of Sunshin mine, one of the several active metal mines in Korea. Sunshin mine has been developed since January 2002 with production from Eunsan deposit, and the production of Moisan deposit was followed in 2006. The combined mine production from the two deposits up to April 2008 was $1222 \mathrm{~kg}$ Au and 31,058 kg Ag [27-29].

A polished section was prepared of the ore sample and studied under reflected light microscopy to identify the ore minerals. The rest of the ore sample was crushed and pulverized to $0.075 \mathrm{~mm}$ size, using a disc mill. The mineral compositions were determined by X-ray diffraction (XRD) using an X'Pert Pro MRD (Philips, Amsterdam, The Netherland) from PANalytical in the Netherlands. For the determination of the chemical compositions, in particular $\mathrm{Au}, \mathrm{Ag}, \mathrm{As}$, and total $\mathrm{Fe}$, a sample was 
pretreated by aqua regia digestion and analyzed using atomic absorption spectrophotometry (AAS) using a Shimadzu AA-7000 (Shimadzu, Kyoto, Japan) from Japan. The major element composition was determined by X-ray fluorescence (XRF) using a Rigaku ZSX Primus II (Rigaku, Tokyo, Japan) from Japan.

\subsection{Reductive Microwave Roasting (RMR)-Magnetic Separation (MS) Process}

The overall processes of RMR-MS are shown in Figure 1.

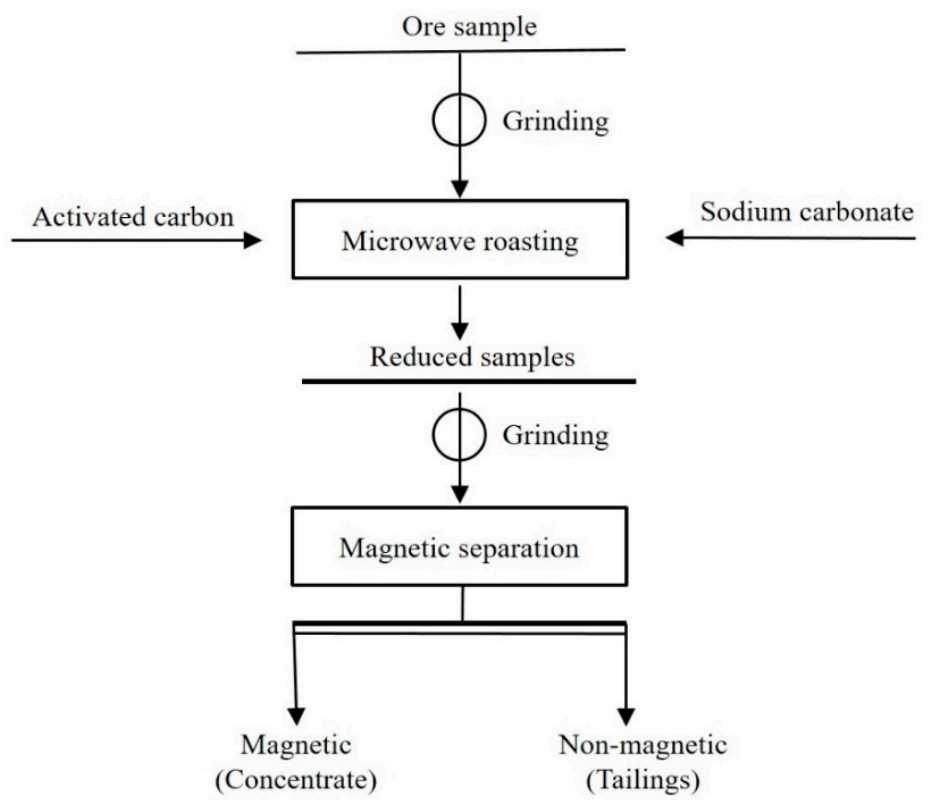

Figure 1. Reductive microwave roasting (RMR) and magnetic separation (MS) processes.

\subsubsection{RMR Process}

RMR processing was conducted as a pre-processing to separate the Fe-oxides from the auriferous ore in the near-surface oxide zone. The microwave roasting process, especially controlling irradiation time, could be used to control the mineral phase change of ore sample [29]. For the reduction of hematite, various reducing agents, such as activated carbon, sodium carbonate and charcoal, have been used in the reductive roasting process [30-32]. In this study, the pulverized ore sample was mixed with activated carbon and sodium carbonate in a closed crucible $(7.5 \mathrm{~cm}$ diameter by $25 \mathrm{~cm}$ height). Here, the activated carbon was added to the ore sample as a reducing agent. The ore mixture was irradiated with a microwave using a microwave generator. The microwave generator was a batch-type device operating at $2450 \mathrm{MHz}$ with adjustable power of 1-6 kW. The microwave irradiation test was conducted under different conditions of reducing agent (Exps. A and B), microwave power (Exps. C) and irradiation time (Exps. D). Details of the different conditions during the experiment are given in Table 1.

Table 1. Experimental conditions of the reductive microwave roasting (RMR).

\begin{tabular}{ccccc}
\hline Experiments & A & B & C & D \\
\hline Ore Sample $(\mathrm{g})$ & 50 & 50 & 50 & 50 \\
Activated Carbon Mass $(\mathrm{g})$ & $25-100$ & 75 & 75 & 75 \\
Sodium Carbonate $(\mathrm{g})$ & 6 & $2-14$ & 10 & 10 \\
Microwave Intensity $(\mathrm{kW})$ & 5 & 5 & $3-6$ & 5 \\
Irradiation time $(\mathrm{min})$ & 10 & 10 & 10 & $7-15$ \\
\hline
\end{tabular}


After the processed sample was cooled sufficiently in ambient conditions, an aggregated ore mixture was obtained. Polished thin sections were prepared using a part of the aggregated samples. The RMR-processed sample was ground using a ball mill with a 10:1 material ratio at a rotational speed $300 \mathrm{r} / \mathrm{min}$ for $15 \mathrm{~min}$. Part of the powdered sample was pretreated by aqua regia digestion and analyzed using AAS to determine the chemical content of the RMR-processed samples.

\subsubsection{MS Process}

Magnetic separation was conducted for the RMR-processed samples after milling the aggregate particles. For a comparison, magnetic separation was also conducted for the raw sample without RMR treatment. The magnetic separation was carried out using a Davis tube magnetic separator (XCGS-73, Changsha Research Institute of Mining and Metallurgy Co., Changsha, China) for 20 min with a magnetic intensity of $4500 \mathrm{G}$. The weights of the magnetic concentrate and non-magnetic tailings were measured to calculate magnetic fraction.

The chemical composition and iron grade of the magnetic concentrate and non-magnetic tailings were determined through aqua regia digestion and AAS. In order to study the effect of MS process on the magnetic property obtained by the transformation of hematite, the magnetic hysteresis and magnetic intensity were analyzed using Vibration Sample magnetometer (VSM, BHV-50HTI, Riken, Keiki, Japan).

\section{Results and Discussion}

\subsection{Characteristics of Ore in the Near-Surface Oxide Zone}

The major element composition and mineralogical characteristics of the ore sample are presented in Table 2. The ore contains high concentrations of precious metals; $6.4 \mathrm{mg} / \mathrm{kg}$ of gold and $35.6 \mathrm{mg} / \mathrm{kg}$ of silver, as well as deleterious elements, such as $911.6 \mathrm{mg} / \mathrm{kg}$ of As. The composition of the total iron in the ore sample accounted for $28.6 \mathrm{wt}$. \%. Hematite $\left(\mathrm{Fe}_{2} \mathrm{O}_{3}\right)$ is the most abundant Fe-oxide mineral and accounts for $64 \%$ of the total iron content in the sample. The high concentrations of $\mathrm{SiO}_{2}$ and $\mathrm{Al}_{2} \mathrm{O}_{3}$ were related to the occurrence of quartz and muscovite in the ore sample from the near-surface oxide zone (Figure 2).

Table 2. XRF and AAS analysis for the ore sample from near-surface oxide zone in Moisan Gold deposit (Haenam, South Korea). The contents of the target elements such as Au, Ag, As and total Fe were analyzed using AAS. The mineral compositions were determined XRF analysis.

\begin{tabular}{rcccccccccccc}
\hline Element/Mineral & $\mathrm{Au}$ & $\mathrm{Ag}$ & $\mathrm{As}$ & $\mathrm{T} \mathrm{Fe}$ & $\mathrm{Fe}_{2} \mathrm{O}_{3}$ & $\mathrm{SiO}_{2}$ & $\mathrm{Al}_{2} \mathrm{O}_{3}$ & $\mathrm{Na}_{2} \mathrm{O}$ & $\mathrm{SO}_{3}$ & $\mathrm{~K}_{2} \mathrm{O}$ & $\mathrm{CaO}$ & $\mathrm{TiO}_{2}$ \\
\hline Contents (wt. \%) & $6.4^{\mathrm{a}}$ & $35.6^{\mathrm{a}}$ & $911.6^{\mathrm{a}}$ & 28.6 & 26.2 & 24.2 & 6.8 & 2.1 & 6.8 & 2.4 & 3.1 & 0.9 \\
\hline \multicolumn{8}{c}{${ }^{\mathrm{a}} \mathrm{mg} / \mathrm{kg}}$. & & \multicolumn{8}{c}{}
\end{tabular}

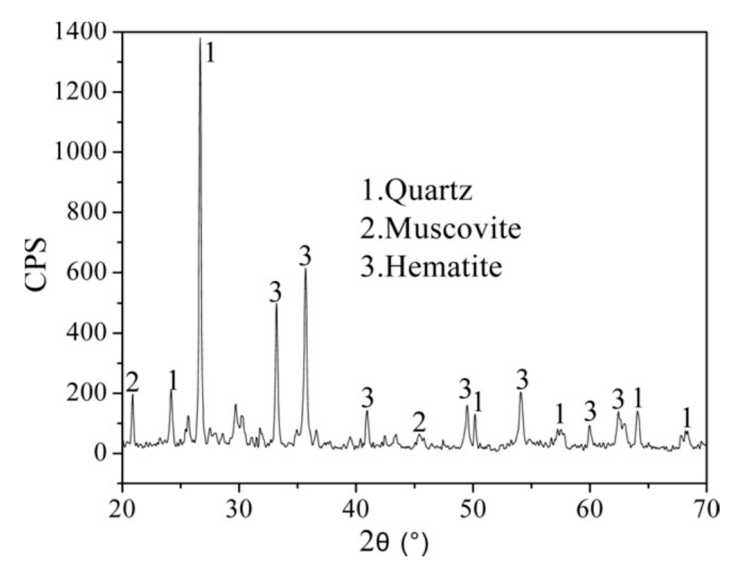

Figure 2. XRD pattern for the ore sample from the near-surface oxide zone. 
Polarized light microscopy identified spherical hematite particles associated with cubic pyrite crystals (Figure $3 a, b$ ) that formed through the leaching of pyrite by acidic water (i.e., supergene fluid). The acidic water with Fe in solution also formed fine veins and penetrated cubic spaces where it deposited the spherical hematite particles (Figure 3c). The dissolved iron also formed concentric hematite structures within the veins (Figure 3d), which is commonly observed in the oxide zone [33].
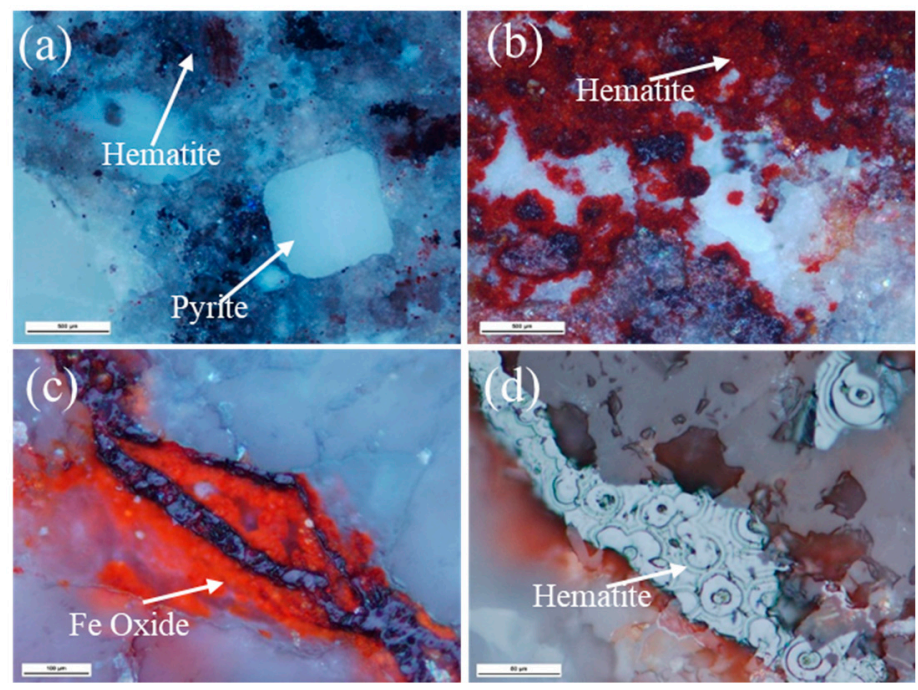

Figure 3. Reflected light microphotographs of the hematite in the oxidation zone sample. $(\mathbf{a}-\mathbf{c})$ are in cross-polarized light and (d) is in plane-polarized light.

\subsection{RMR-MS for Recovery of Au Concentrate from Oxide Ore}

The raw sample had sufficiently high levels of gold and silver, but a high content of hematite in the Fe-oxide reduced the effectiveness of gold recovery processes, such as flotation. The RMR-MS process was tested as a method for the efficient separation of Fe-oxides from the auriferous ore in the near-surface oxide zone. The effect of the RMR-MS process on the composition of the concentrate was evaluated by comparing with the compositions of the raw and MS-processed samples (Table 3). Here, the RMR was conducted on 50-g of pulverized ore using $75 \mathrm{~g}$ of activated carbon and $10 \mathrm{~g}$ of sodium carbonate. Microwave irradiation took place at $5 \mathrm{~kW}$ for $10 \mathrm{~min}$. RMR-MS-processed ore sample showed increased contents of $\mathrm{Au}, \mathrm{Ag}$ and Fe. The content of $\mathrm{Au}$ increased from 6.4 to $10.8 \mathrm{mg} / \mathrm{kg}$ and $\mathrm{Ag}$ content from 35.6 to $43.2 \mathrm{mg} / \mathrm{kg}$. The total iron content increased from 28.6 to 41.9 wt. \% but the content of $\mathrm{Fe}_{2} \mathrm{O}_{3}$ decreased from $26.2 \%$ to $2.7 \%$. This indicates that $\mathrm{Fe}_{2} \mathrm{O}_{3}$ reduced and changed into magnetic minerals during the microwave roasting process and that the magnetic fraction of the RMR treated ore was successfully separated by the MS process. The ratios of $\mathrm{Au} /$ total $\mathrm{Fe}$ and $\mathrm{Ag} /$ total Fe shows that $\mathrm{Au}$ and Ag migrated with the Fe-oxide minerals during the MS process. This suggests that successful separation of Fe-oxides could be an effective method for increasing gold recovery. In addition, as content decreased from 911.6 to $10.5 \mathrm{mg} / \mathrm{kg}$ during RMR-MS process by evaporation of $\mathrm{As}_{2} \mathrm{O}_{3}$. The noticeable elimination of the penalty element could increase the value of the ore concentrate. The raw sample and magnetic fraction showed similar ratios of $\mathrm{Au} / \mathrm{Fe}_{2} \mathrm{O}_{3}$ and $\mathrm{Ag} / \mathrm{Fe}_{2} \mathrm{O}_{3}$. This supports the concept that gold and silver in hematite are effectively recovered by the magnetic separation after mineral phase change of hematite to magnetic minerals.

The mineral phase change was observed in the image of reflected light microphotograph for the RMR-MS-processed sample. Figure 4a shows a core-rim structure with hematite along the boundary and magnetite making up the core of the mineral. This structure could be generated through a number of processes: (1) the mineralogical transformation of Fe-oxide minerals from the interior site by energy focusing; (2) by the uniform distribution of temperature through the mineral with lower stresses at the grain boundaries [22]; or (3) during the microwave sintering of pyrite by the dissolution re-precipitation mechanism [3]. 
Table 3. Composition of $\mathrm{Au}, \mathrm{Ag}$, $\mathrm{As}$, $\mathrm{Fe}$ and hematite $\left(\mathrm{Fe}_{2} \mathrm{O}_{3}\right)$ in the raw ore sample and RMR-MS processed samples.

\begin{tabular}{cccccc}
\hline Sample & Au & Ag & As & T Fe (wt. \%) & $\mathbf{F e}_{2} \mathbf{O}_{3}$ (wt. \%) \\
\hline Raw & 6.4 & 35.6 & 911.6 & 28.6 & 26.2 \\
RMR-MS processed $^{\text {a }}$ & 10.8 & 43.2 & 10.5 & 41.9 & 1.9
\end{tabular}

a RMR was conducted on $50 \mathrm{~g}$ of pulverized ore using $75 \mathrm{~g}$ of activated carbon and $10 \mathrm{~g}$ of sodium carbonate. Microwave irradiation took place at $5 \mathrm{~kW}$ for $10 \mathrm{~min}$.

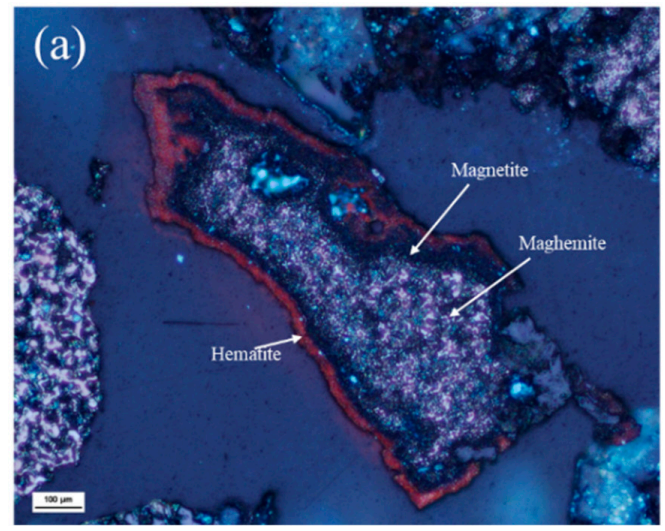

(b) Mh maghemite; JCPDs; 2481

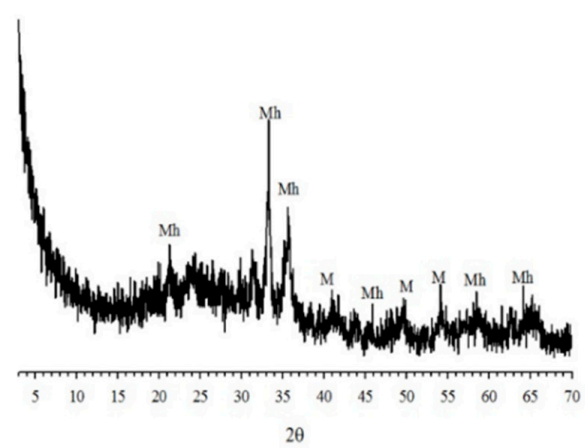

Figure 4. (a) Reflected light microphotograph showing mineral phase change from hematite to magnetite and maghemite. (b) X-ray diffraction pattern of the magnetic fraction from the roasted sample. The sample was treated with $5 \mathrm{~kW}$ of microwave power in Exps. C.

The XRD pattern for the magnetic fraction after RMR shows the generation of magnetic minerals such as maghemite $\left(\gamma-\mathrm{Fe}_{2} \mathrm{O}_{3}\right)$, which has ferromagnetic properties, and magnetite (Figure $3 \mathrm{~b}$ ). Maghemite can be produced along with magnetite by the reduction of hematite at high temperature, with oxidation upon contact with air during cooling [1]. The increase in the magnetization of the roasted sample is illustrated by comparing the magnetic hysteresis loops of the raw and roasted samples (Figure 5). The curves show that the saturation magnetization significantly increased from 2.74 to $26.91 \mathrm{emu} / \mathrm{g}$ after reduction roasting. The reduction of hematite using electric furnaces reported an increase in saturation magnetization intensities $(M s)$ from 9 to $37 \mathrm{emu} / \mathrm{g}$ by the complete conversion of hematite to magnetite [34]. Good magnetic separation could be achieved after roasting since the residual magnetism $(\mathrm{Mr})$ increased from 0.5 to $3.9 \mathrm{emu} / \mathrm{g}$ [34].

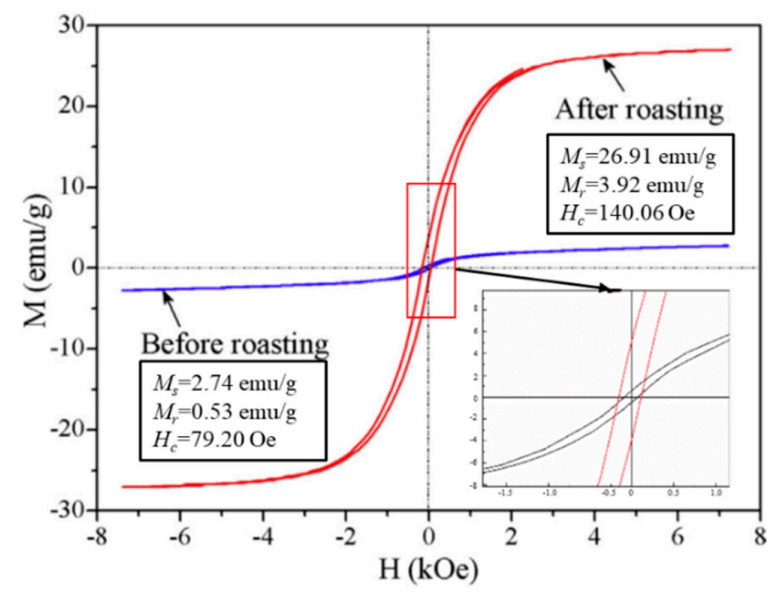

Figure 5. Magnetic hysteresis loops of the raw sample and magnetic fraction from the roasted sample. The roasted sample was treated with $5 \mathrm{~kW}$ of microwave power in Exps. C. 


\subsection{Effects of RMR Conditions on Iron Recovery}

The effective recovery of gold from the near-surface oxide zone using RMR and magnetic separation (MS), requires the efficient reduction of hematite. The RMR-MS tests were conducted under different conditions of reducing agents (contents of activated carbon and sodium carbonate) and microwave operation (microwave power and irradiation time), to optimize the RMR process for gold recovery. In the following, the effects of the operation conditions on the recovery of iron minerals coexisting with gold were investigated to better understand the gold recovery.

\subsubsection{Effect of Activated Carbon and Sodium Carbonate}

Figure 6 shows the results of RMR experiments that were conducted using different concentrations of activated carbon and sodium carbonate. Hematite was not sufficiently reduced through microwave irradiation without activated carbon, which clearly illustrates that a reducing agent, such as activated carbon is essential for the reduction of hematite by microwave roasting (Figure 6a). The results show an increase in grade and recovery of iron associated with an increase in the concentration of activated carbon, but a rapid decrease in both indices when the carbon-to-ore ratio is less than 1.5 . This may be explained by the incomplete reduction of hematite when the activated carbon is insufficient, and an over-reduction of hematite to ferrous oxide when activated carbon is excessive. This illustrates the important effect of the ratio of activated carbon-to-iron-oxide minerals on iron recovery. The optimal ratio of activated carbon-to-ore was determined to be 1.5. At this ratio, the activated carbon acted as a microwave susceptor, as well as a reducing agent $[4,35]$. When activated carbon is irradiated with microwaves, $\mathrm{CO}_{2}$ and $\mathrm{CO}$ gases are generated sequentially by heat (Equation (1)) and by Boudouard's reaction (Equation (2)), respectively $[25,36]$. The generated CO can reduce hematite to magnetite by the reaction in Equation (3) [37].

$$
\begin{gathered}
\mathrm{C}+\mathrm{O}_{2}=\mathrm{CO}_{2} \\
\mathrm{C}+\mathrm{CO}_{2}=2 \mathrm{CO} \\
3 \mathrm{Fe}_{2} \mathrm{O}_{3}+\mathrm{CO}=2 \mathrm{Fe}_{3} \mathrm{O}_{4}+\mathrm{CO}_{2}
\end{gathered}
$$
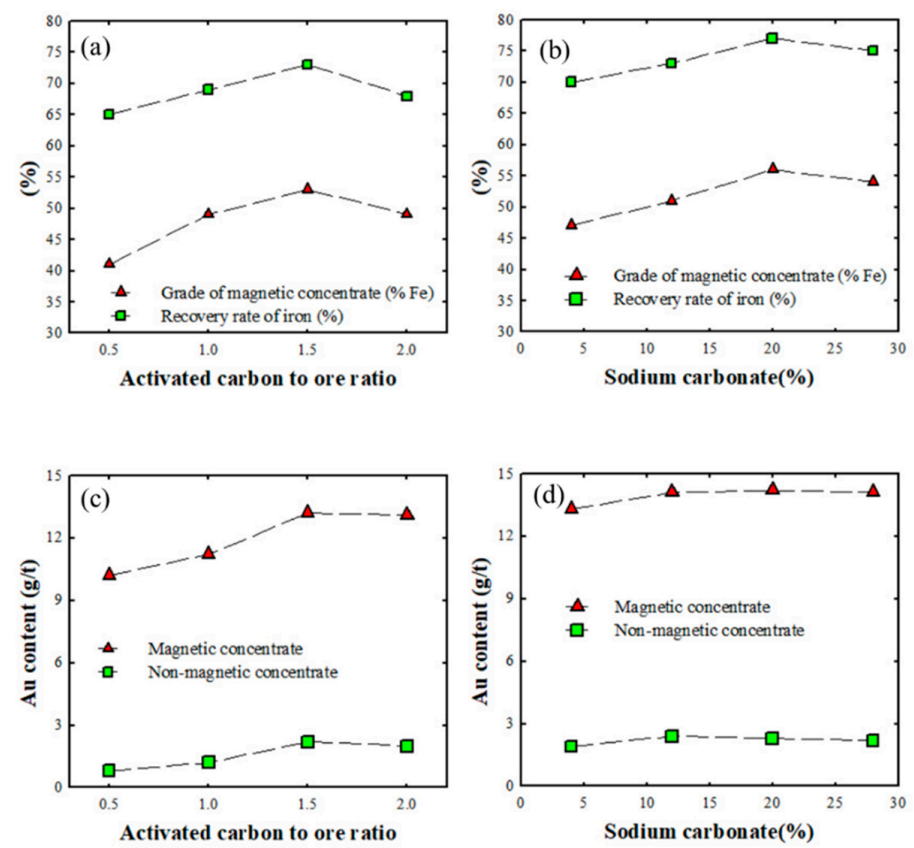

Figure 6. Effects of $(\mathbf{a}, \mathbf{c})$ activated carbon and $(\mathbf{b}, \mathbf{d})$ sodium carbonate concentrations on iron $(\mathbf{a}, \mathbf{b})$ and gold $(\mathbf{c}, \mathbf{d})$ recovery. 
$\mathrm{Na}_{2} \mathrm{CO}_{3}$ was added along with the activated carbon to increase the reduction of ore during the RMR process [38]. In our study, different amounts of $\mathrm{Na}_{2} \mathrm{CO}_{3}$ were added for microwave roasting. Figure $6 \mathrm{~b}$ shows the grade and recovery of iron as a function of the $\mathrm{Na}_{2} \mathrm{CO}_{3}$ dosage. The maximum recovery of iron increased up to $77 \%$ by adding $20 \%$ of sodium carbonate and an additional supply of $\mathrm{CO}_{2}$, which is essential for the reductive roasting of hematite (Equation 2). $\mathrm{Na}_{2} \mathrm{CO}_{3}$ melts at $874{ }^{\circ} \mathrm{C}$ and produces $\mathrm{CO}_{2}\left(\mathrm{Na}_{2} \mathrm{CO}_{3} \rightarrow \mathrm{Na}_{2} \mathrm{O}+\mathrm{CO}_{2}\right)$. Therefore, the production of $\mathrm{CO}_{2}$ gas by the addition of $\mathrm{Na}_{2} \mathrm{CO}_{3}$ facilitated the reduction of hematite to magnetite [39,40]. This, in turn, improves the efficiency of magnetic separation [5,41,42].

Figure $6 \mathrm{a}, \mathrm{b}$ shows reduced iron recovery at high levels of activated carbon and sodium carbonate. This can be explained by the reduction process of hematite. According to the principle of Baykova, reduction of Fe-oxides, such as hematite, takes place in three steps: $\mathrm{Fe}_{2} \mathrm{O}_{3} \rightarrow \mathrm{Fe}_{3} \mathrm{O}_{4} \rightarrow \mathrm{FeO} \rightarrow \mathrm{Fe}$ [43]. Due to the non-magnetic properties of $\mathrm{FeO}$, the generation of $\mathrm{FeO}$ by high levels of reduction inhibits the efficient recovery of iron. Figure $6 \mathrm{c}$ shows the increase of gold content by increasing dosage of activated carbon, but the addition of sodium carbonate did not show any significant change in gold content (Figure 6d).

\subsubsection{Effect of Microwave Power and Irradiation Time}

The microwave process was optimized through different operation conditions of the microwaves in the RMR for ore from the near-surface oxide zone. Figure 7a,c shows that both grade and recovery of iron increased rapidly when the microwave power increased from 3 to $5 \mathrm{~kW}$, but decreased when the microwave power increased to $6 \mathrm{~kW}$. In Figure $7 \mathrm{~b}, \mathrm{~d}$, the grade and recovery of iron and gold increased with increasing irradiation time, but prolonged irradiation inhibited the efficient recovery of iron and gold. This could be due to over-reduced hematite to weakly magnetic ferrous oxide, such as $\mathrm{FeO}$. In this RMR condition, $5 \mathrm{~kW}$ of microwave power and $10 \mathrm{~min}$ of irradiation are the optimum conditions for the effective recovery of iron and gold.
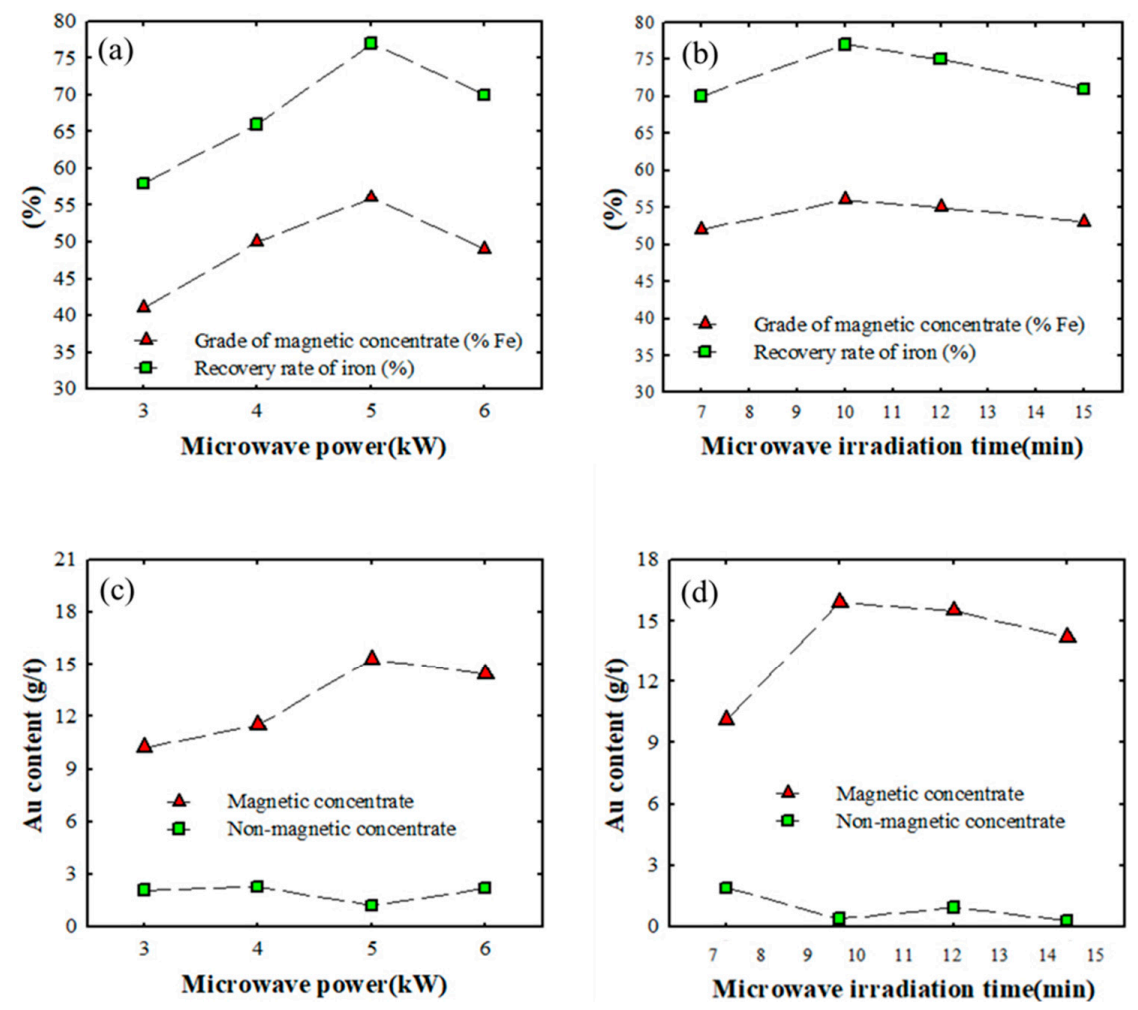

Figure 7. Effect of reduction roasting conditions ( $(\mathbf{a}, \mathbf{c})$ microwave intensity and $(\mathbf{b}, \mathbf{d})$ irradiation time) on the $\mathrm{Fe}(\mathbf{a}, \mathbf{b})$ and $\mathrm{Au}(\mathbf{c}, \mathbf{d})$ contents in the ores from the near-surface oxide zone. 


\subsection{Au Concentration during RMR-MS}

RMR-MS-processed samples showed an increase in iron grade and gold contents. The enhancements of the gold content and iron grade, which were obtained through RMR-MS test under various conditions of RMR, are shown together in Figure 8. The result shows that the gold content increase is closely related to the increase of the iron grade. This is because gold and silver show the same behaviors with iron at the gossan and the oxidation zone [44]. This suggests that the separation of iron-bearing minerals obtained through reduction of oxide minerals is applicable as an effective method for gold recovery from the ores in near-surface oxide zone.
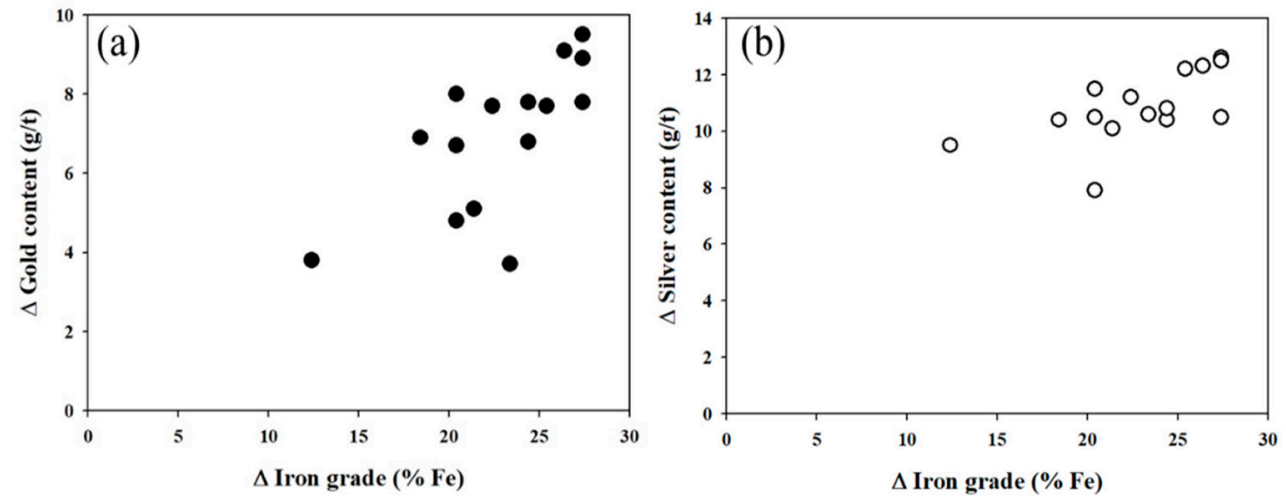

Figure 8. (a) Increases $(\Delta)$ of gold contents and (b) silver contents during the increase of iron grade in RMR-MS processed concentrates. All data obtained in the overall RMR-MS tests in this study was plotted. (Raw ore sample contained 6.4 and $35.6 \mathrm{~g} / \mathrm{t}$ of gold and silver and $28.6 \%$ of iron).

\section{Conclusions}

This research focused on the recovery of high-grade Au associated with a near-surface oxide zone through RMR-MS. The main mineral phases in the ore sample from the near-surface oxide zone are hematite, quartz, and muscovite. Microwave irradiation enhanced the recovery of iron through magnetic separation by transforming hematite to magnetic iron minerals, such as magnetite and maghemite. Gold and silver that coexist with hematite are also recovered efficiently by this operation. The microwave treatment also removed arsenic, a deleterious element. Reductive microwave roasting needs to be optimized because the over-reduction of hematite could generate weakly magnetic ferrous minerals, which inhibit the recovery of iron. Efficient iron recovery (which could also be an indicator of Au recovery), is influenced by the microwave process conditions, as well as the reducing agents, such as activated carbon and sodium carbonate. The RMR-MS process is a promising method to extract gold from a near-surface oxide zone. This process allows for most of the gold in a near-surface oxide zone to be extracted during mining.

Author Contributions: Conceptualization, N.-C.C. and S.L.; methodology, N.-C.C.; software, K.H.C.; validation, K.H.C. and S.-G.L.; formal analysis, B.-J.K.; investigation, B.-J.K.; resources, B.-J.K.; data curation, B.-J.K. and S.L.; writing-original draft preparation, B.-J.K.; writing-review and editing, S.L.; visualization, S.-G.L.; supervision, C.-Y.P.; project administration, N.-C.C.; funding acquisition, C.-Y.P.

Funding: This research was funded by the Korean Ministry of Environment (MOE), grant number 2016000140010.

Acknowledgments: This study was supported by the Korean Ministry of Environment (MOE) as part of the "Advanced Technology Program for Environmental Industry" (Technologies for the Risk Assessment and Management 2016000140010).

Conflicts of Interest: The authors declare no conflict of interest.

\section{References}

1. Wu, Y.; Fang, M.; Lan, L.D.; Zhang, P.; Rao, K.V.; Bao, Z.Y. Rapid and direct magnetization of goethite ore roasted by biomass fuel. Sep. Purif. Technol. 2012, 94, 34-38. [CrossRef] 
2. Gao, G.; Li, D.; Zhou, Y.; Sun, X.; Sun, W. Kinetics of high-sulphur and high-arsenic refractory gold concentrate oxidation by dilute nitric acid under mild conditions. Miner. Eng. 2009, 22, 111-115. [CrossRef]

3. Mari, D.; Bolognini, S.; Feusier, G.; Cutard, T.; Verdon, C.; Viatte, T.; Benoit, W. Timocn based cermets: Part I. Morphology and phase composition. Int. J. Refract. Met. Hard Mater. 2003, 21, 37-46. [CrossRef]

4. Hayashi, M.; Takeda, K.; Kashimura, K.; Watanabe, T.; Nagata, K. Carbothermic reduction of hematite powders by microwave heating. Isij Int. 2013, 53, 1125-1130. [CrossRef]

5. Li, G.H.; Zhang, S.H.; Rao, M.J.; Zhang, Y.B.; Jiang, T. Effects of sodium salts on reduction roasting and Fe-P separation of high-phosphorus oolitic hematite ore. Int. J. Miner. Process. 2013, 124, 26-34. [CrossRef]

6. Zhang, M.; Peng, Y.J. Effect of clay minerals on pulp rheology and the flotation of copper and gold minerals. Miner. Eng. 2015, 70, 8-13. [CrossRef]

7. Celep, O.; Alp, İ.; Paktunç, D.; Thibault, Y. Implementation of sodium hydroxide pretreatment for refractory antimonial gold and silver ores. Hydrometallurgy 2011, 108, 109-114. [CrossRef]

8. Dunn, J.G.; Chamberlain, A.C. The recovery of gold from refractory arsenopyrite concentrates by pyrolysis-oxidation. Miner. Eng. 1997, 10, 919-928. [CrossRef]

9. Gudyanga, F.P.; Mahlangu, T.; Roman, R.J.; Mungoshi, J.; Mbeve, K. An acidic pressure oxidation pre-treatment of refractory gold concentrates from the kwekwe roasting plant, zimbabwe. Miner. Eng. 1999, 12, 863-875. [CrossRef]

10. Iglesias, N.; Carranza, F. Refractory gold-bearing ores: A review of treatment methods and recent advances in biotechnological techniques. Hydrometallurgy 1994, 34, 383-395. [CrossRef]

11. Celep, O.; Alp, İ; Deveci, H. Improved gold and silver extraction from a refractory antimony ore by pretreatment with alkaline sulphide leach. Hydrometallurgy 2011, 105, 234-239. [CrossRef]

12. Celep, O.; Serbest, V. Characterization of an iron oxy/hydroxide (gossan type) bearing refractory gold and silver ore by diagnostic leaching. Trans. Nonferrous Met. Soc. China 2015, 25, 1286-1297. [CrossRef]

13. Lunt, D.; Weeks, T. Chapter 7-Process flowsheet selection. In Gold ore Processing, 2nd ed.; Adams, M.D., Ed.; Elsevier: Amsterdam, The Netherlands, 2016; pp. 113-129.

14. Faraz, S.; Hossna, D.; Rezgar, B.; Piroz, Z. Improved recovery of a low-grade refractory gold ore using flotation-preoxidation-cyanidation methods. Int. J. Min. Sci. Technol. 2014, 24, 537-542. [CrossRef]

15. La Brooy, S.R.; Linge, H.G.; Walker, G.S. Review of gold extraction from ores. Miner. Eng. 1994, 7, $1213-1241$. [CrossRef]

16. Learmont, M.; Iwasaki, I. Effect of grinding media on galena flotation. Min. Metall. Explor. 1984, 1, $136-143$. [CrossRef]

17. Bandini, P.; Prestidge, C.A.; Ralston, J. Colloidal iron oxide slime coatings and galena particle flotation. Miner. Eng. 2001, 14, 487-497. [CrossRef]

18. Parsonage, P. Effects of slime and colloidal particles on the flotation of galena. Flotat. Sulphide Miner. 1984, 111-139.

19. Peng, Y.J.; Zhao, S.L. The effect of surface oxidation of copper sulfide minerals on clay slime coating in flotation. Miner. Eng. 2011, 24, 1687-1693. [CrossRef]

20. Zhang, Y.; Li, H.; Yu, X. Recovery of iron from cyanide tailings with reduction roasting-water leaching followed by magnetic separation. J. Hazard. Mater. 2012, 213-214, 167-174. [CrossRef] [PubMed]

21. Viñals, J.; Roca, A.; Cruells, M.; Núñez, C. Characterization and cyanidation of rio tinto gossan ores. Can. Metall. Q. 1995, 34, 115-122. [CrossRef]

22. Znamenáčková, I.; Lovas, M.; Mockovčiaková, A.; Jakabský, Š.; Briančin, J. Modification of magnetic properties of siderite ore by microwave energy. Sep. Purif. Technol. 2005, 43, 169-174. [CrossRef]

23. Omran, M.; Fabritius, T.; Elmandy, A.M.; Abdel-Khalek, N.A.; El-Aref, M.; Elmanawi, A.E.H. Effect of microwave pre-treatment on the magnetic properties of iron ore and its implications on magnetic separation. Sep. Purif. Technol. 2014, 136, 223-232. [CrossRef]

24. Barani, K.; Koleini, S.M.J.; Rezaei, B. Magnetic properties of an iron ore sample after microwave heating. Sep. Purif. Technol. 2011, 76, 331-336. [CrossRef]

25. Nanthakumar, B.; Pickles, C.A.; Kelebek, S. Microwave pretreatment of a double refractory gold ore. Miner. Eng. 2007, 20, 1109-1119. [CrossRef]

26. Roca, A. Characterization and alkaline decomposition/cyanidation of beudantite-jarosite materials from rio tinto gossan ores. Can. Metall. Q. 1999, 38, 93-103. [CrossRef] 
27. Choi, S.-G.; Ryu, I.-C.; Pak, S.J.; Wee, S.-M.; Kim, C.S.; Park, M.-E. Cretaceous epithermal gold-silver mineralization and geodynamic environment, korea. Ore Geol. Rev. 2005, 26, 115-135. [CrossRef]

28. Kim, C.S.; Choi, S.G. Potassium-argon ages of the epithermal gold-silver mineralization in the haenam-jindo area, southwestern korea. Resour. Geol. 2009, 59, 415-421. [CrossRef]

29. Choi, N.-C.; Kim, B.-J.; Cho, K.; Lee, S.; Park, C.-Y. Microwave pretreatment for thiourea leaching for gold concentrate. Metals 2017, 7, 404. [CrossRef]

30. Li, J.; Li, B.W.; Wang, L.; Wang, S.B. Study of reduction characteristic on microwave magnetizing roast of hematite. Adv. Mater. Res. 2011, 284-286, 1237-1243. [CrossRef]

31. Foo, K.; Hameed, B. Potential of jackfruit peel as precursor for activated carbon prepared by microwave induced naoh activation. Bioresour. Technol. 2012, 112, 143-150. [CrossRef] [PubMed]

32. Amankwah, R.; Pickles, C. Microwave roasting of a carbonaceous sulphidic gold concentrate. Miner. Eng. 2009, 22, 1095-1101. [CrossRef]

33. Paktunc, D.; Kingston, D.; Pratt, A.; McMullen, J. Distribution of gold in pyrite and in products of its transformation resulting from roasting of refractory gold ore. Can. Mineral. 2006, 44, 213-227. [CrossRef]

34. Xu, C.; Sun, T.; Jue, K.; Li, Y.; Mo, X.; Tang, L. Mechanism of phosphorus removal in beneficiation of high phosphorous oolitic hematite by direct reduction roasting with dephosphorization agent. Trans. Nonferrous Met. Soc. China 2012, 22, 2806-2812. [CrossRef]

35. Pracejus, B. The Ore Minerals under the Microscope: An Optical Guide; Elsevier: Amsterdam, The Netherlands, 2015.

36. Samouhos, M.; Hutcheon, R.; Paspaharis, L. Microwave reduction of copper(ii) oxide and malachite concentrate. Miner. Eng. 2011, 24, 903-913. [CrossRef]

37. Aguilar, J.A.; Gomez, I. Microwaves applied to carbothermic reduction of iron ore pellets. J. Microw. Power Electromagn. Energy 1997, 32, 67-73. [CrossRef]

38. Seyrankaya, A.; Ozalp, B. Dehydration of sodium carbonate monohydrate with indirect microwave heating. Thermochim. Acta 2006, 448, 31-36. [CrossRef]

39. Bai, S.J.; Wen, S.M.; Liu, D.W.; Zhang, W.B.; Cao, Q.B. Beneficiation of high phosphorus limonite ore by sodium-carbonate-added carbothermic reduction. ISIJ Int. 2012, 52, 1757-1763. [CrossRef]

40. Zhu, D.Q.; Chun, T.J.; Pan, J.; He, Z. Recovery of iron from high-iron red mud by reduction roasting with adding sodium salt. J. Iron Steel Res. Int. 2012, 19, 1-5. [CrossRef]

41. Bai, S.J.; Wen, S.M.; Liu, D.W.; Zhang, W.B.; Xian, Y.J. Catalyzing carbothermic reduction of siderite ore with high content of phosphorus by adding sodium carbonate. ISIJ Int. 2011, 51, 1601-1607. [CrossRef]

42. Basumallick, A. Influence of $\mathrm{CaO}$ and $\mathrm{Na}_{2} \mathrm{CO}_{3}$ as additive on the reduction of hematite-lignite mixed pellets. ISIJ Int. 1995, 35, 1050-1053. [CrossRef]

43. Huang, Z.; Guo, Z.; Calka, A.; Wexler, D.; Lukey, C.; Liu, H.-K. Effects of iron oxide $\left(\mathrm{Fe}_{2} \mathrm{O}_{3}, \mathrm{Fe}_{3} \mathrm{O}_{4}\right)$ on hydrogen storage properties of Mg-based composites. J. Alloys Compd. 2006, 422, 299-304. [CrossRef]

44. Lavaud, T.; Beziat, D.; Blot, A.; Debat, P.; Lompo, M.; Martin, F.; Ouangrawa, M.; Tollon, F. Paleo-gossans within the lateritic iron crust: Example of the nickeliferous prospect of bonga, burkina faso. J. Afr. Earth. Sci. 2004, 39, 465-471. [CrossRef]

(C) 2018 by the authors. Licensee MDPI, Basel, Switzerland. This article is an open access article distributed under the terms and conditions of the Creative Commons Attribution (CC BY) license (http://creativecommons.org/licenses/by/4.0/). 